\title{
Results from Chile's 2018 Report Card on Physical Activity for Children and Youth
}

\author{
Nicolas Aguilar-Farias, Sebastian Miranda-Marquez, Kabir P. Sadarangani, \\ Pia Martino-Fuentealba, Carlos Cristi-Montero, Jaime Carcamo-Oyarzun, Pedro Delgado-Floody, \\ Damian Chandia-Poblete, Camila Mella-Garcia, Fernando Rodriguez-Rodriguez, \\ Astrid Von Oetinger, Teresa Balboa-Castillo, Sebastian Peña, Cristobal Cuadrado, \\ Paula Bedregal, Carlos Celis-Morales, Antonio García-Hermoso, and Andrea Cortinez-O'Ryan
}

\section{Introduction}

Chile's first Report Card (RC) on Physical Activity for Children and Youth released in 2016 graded with an F overall physical activity (PA), as only 3 out of 10 children and 2 out of 10 youth performed at least 60 minutes of moderate-to vigorous-intensity PA per day. ${ }^{1}$ Most indicators received very low grades, except for Community and Environment, and Government Strategies and Investments. In the present study, we aimed to summarize the results of the Chile's second RC for 13 PA-related indicators.

\section{Methods}

The 2018 Chile's RC (Figure 1) included the 10 core PA indicators that are common to the Global Matrix 3.0: Overall Physical Activity, Organized Sport Participation, Active Play, Active Transportation, Sedentary Behaviors, Physical Fitness, Family and Peers, School, Community and Environment, and Government. Additionally, we have included 3 additional indicators: Sleep, Inclusion, and Overweight and obesity. Each of these 13 indicators contributes to one of these three categories: a) Behaviors that contribute to overall PA levels, b) Factors associated with cardiometabolic risk, and c) Factors that influence PA.

The 2018 Chile's RC was developed by a Scientific (SC) and an Advisory committees (AC) consisting of academics and civil servants from all areas represented in the current RC. Members of the SC performed a systematic search of the literature and available data sources, while the AC facilitated access to relevant national surveys that may have included some of the indicators of the RC and provided feedback on the grades.

The 2018 Chile's RC summarized data from the different sources to inform the 13 indicator grades based on a standardised grading system (grades ranged from $\mathrm{A}$ to $\mathrm{F}$ ) agreed by the Active Healthy Kids Global Alliance. The data sources included nationally representative surveys, published scientific articles and official technical reports available or released from 2016.

\section{Results and Discussion}

Overall PA was graded with a D-, given that $20.2 \%$ of children and youth (9-18 years old) meet the PA guidelines. In line with the 2016 $\mathrm{RC}$, the highest grades were observed for two of the factors that externally influence PA: Community and environment (B) and Government Strategies and Investments (B-) (Table 1). By contrast, individual behaviors scored grades ranging from $\mathrm{F}$ (Active Transportation) to C- (Sedentary Behaviors). Moreover, in 3 out of 13 indicators we assigned an INCOMPLETE (Active Play, Sleep and Inclusion) as there were not enough data.

The strengths of our analysis include the use of a variety of large, nationally representative data sources and ad-hoc analysis of existing datasets. However, it is noteworthy to mention that data

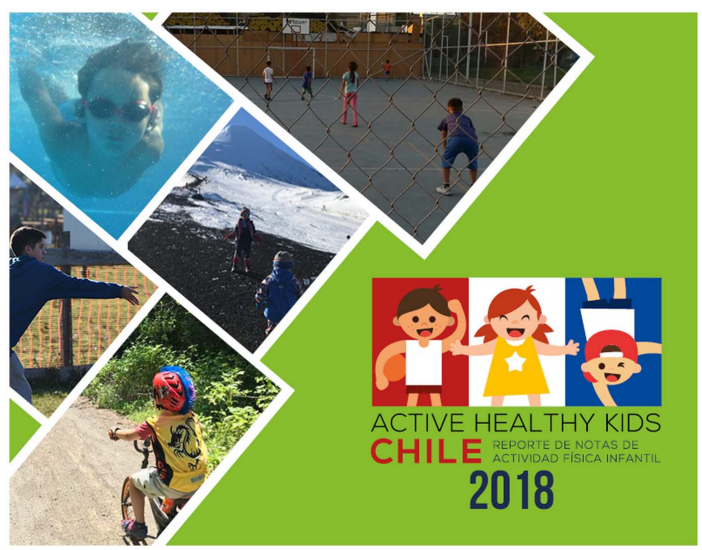

Figure 1 - Chile's 2018 Report Card cover.

Aguilar-Farias, Miranda-Marquez, Martino-Fuentealba, Mella-Garcia, Chandia-Poblete, Carcamo-Oyarzun, Delgado-Floody and Cortinez-O’Ryan are with the Department of Physical Education, Sports and Recreation, Universidad de La Frontera, Chile; and the UFRO Activate Research Group. Sadarangani is with the School of Physiotherapy, Universidad San Sebastian, Chile and the School of Physiotherapy, Universidad Diego Portales, Chile. Cristi-Montero and Rodriguez-Rodriguez are with the IRyS Group, Physical Education School, Pontificia Universidad Catolica de Valparaiso, Chile. Von Oetinger is with the School of Physiotherapy, Universidad San Sebastian, Chile; and the Postgraduate Direction, Universidad Mayor, Chile. Balboa-Castillo is with the Department of Public Health and the Center of Cardiovascular and Nutritional Epidemiology (EPICYN), Universidad de La Frontera, Chile. Peña is with the Department of Public Health Solutions, National Institute for Health and Welfare, Finland; and the Faculty of Medicine, Universidad Diego Portales, Chile. Cuadrado is with the Health Policy, Systems and Management Program, School of Public Health, Universidad de Chile. Bedregal is with the Department of Public Health, Pontificia Universidad Catolica de Chile, Chile. Garcia-Hermoso is with the Laboratory of Physical Activity Sciences, Sports and Health, Universidad de Santiago, Chile. Celis-Morales is with the Centro de Investigacion en Fisiologia del Ejercicio (CIFE), Universidad Mayor, Chile. Aguilar-Farias (nicolas.aguilar@ufrontera.cl) is corresponding author. 
Table 1 Grades and rationales for Chile's 2018 Report Card

\begin{tabular}{|c|c|c|}
\hline Indicator & Grad & Rationale \\
\hline $\begin{array}{l}\text { Overall Physical } \\
\text { Activity }\end{array}$ & D- & $\begin{array}{l}\text { On average, } 20.2 \% \text { of children and adolescents (weighted average) meet the PA guidelines. }{ }^{2-4} 27.4 \% \text { of children ( } 9 \text { to } \\
11 \text { years old) and } 18.9 \% \text { of adolescents meet the PA guidelines based on National data. }{ }^{2-4} \text { There is lack of information } \\
\text { in } 5 \text { to } 8 \text { years old. }\end{array}$ \\
\hline $\begin{array}{l}\text { Organized Sport } \\
\text { Participation }\end{array}$ & D- & $\begin{array}{l}\text { Participation ranged from } 14.4 \% \text { to } 26.3 \% \text { among } 5 \text { to } 17 \text { year-olds., }{ }^{2,5} \text { Very large gender differences across all age } \\
\text { groups were observed, especially between younger and older ages. }{ }^{2}\end{array}$ \\
\hline Active Play & INC & Lack of data to provide a grade for this indicator. \\
\hline Active Transportation & $\mathrm{F}$ & $\begin{array}{l}\text { The weighted average prevalence of active transportation to and from school was } 15 \% \text { ( } 10 \% \text { for children and } 20.0 \% \text { for } \\
\text { adolescents) based on representative data from different cities and regions. }{ }^{6-9}\end{array}$ \\
\hline Sedentary Behaviors & $\mathrm{C}-$ & $\begin{array}{l}\text { Prevalence of }>=2 \mathrm{~h} \text { screen time per day ranged from } 45 \% \text { to } 69 \% \text { in adolescents. Data were extracted from self-report } \\
\text { only and represented two large central regions. } 10,11\end{array}$ \\
\hline Physical Fitness & $\mathrm{D}$ & $\begin{array}{l}\text { Based on } 20-\mathrm{m} \text { shuttle run, girls achieved percentile } 33 \text { and boys percentile } 44 \text {. However, results are limited for } 13 \text { to } \\
15 \text { year-olds. }{ }^{2}\end{array}$ \\
\hline Family and Peers & $\mathrm{F}$ & $\begin{array}{l}12.5 \% \text { of families reported the participation in sporting clubs. }{ }^{5} 86.7 \% \text { of adults do not engage in leisure PA for } \\
30 \text { minutes for } 3 \text { or more times per week. }{ }^{13}\end{array}$ \\
\hline School Environment & $\mathrm{D}$ & $\begin{array}{l}12.8 \% \text { to } 33.0 \% \text { of adolescents reported the participation in physical education for } 3 \text { or more days per week without } \\
\text { gender differences. }{ }^{3,4} 26.0 \% \text { of students reported that they have positive reinforcement from teachers for being } \\
\text { physically active. }{ }^{14}\end{array}$ \\
\hline $\begin{array}{l}\text { Community and } \\
\text { Environment }\end{array}$ & B & $\begin{array}{l}39.0 \text { to } 55.0 \% \text { of adolescents reported good/very good availability of parks, green spaces, cycling infrastructure or } \\
\text { sporting facilities. }{ }^{6} \text { About } 75 \% \text { of children and adolescents reported having a public space for recreation nearby. }{ }^{5} \\
\text { Information was obtained at a national level mostly from adolescents. }\end{array}$ \\
\hline Government & B- & $\begin{array}{l}\text { Chile has a new PA national policy involving three ministries in the design (Sports, Education, and Health). }{ }^{15} \text { It has } \\
\text { implemented a strategic plan with goals and funding in key areas including physical activity. However, there is poor } \\
\text { dissemination and translation to stakeholders. Assessment plan yet to be implemented at a national level. }\end{array}$ \\
\hline
\end{tabular}

Abbreviations: INC, incomplete; PA, physical activity.

were obtained from self-reported measurements, which are subject to bias. In addition, most sources were based on the adolescent population; therefore, children might not be well-represented in our analysis and outcomes must be interpreted with caution.

\section{Conclusion}

Overall, Chile's grades remained low compared with the first RC. On the positive side, Chile is advancing in environmental and policy aspects. Attention should be paid to promote active transportation and support families and peers to promote PA. Our findings indicate that the implementation of new strategies should be developed through collaboration between different sectors to maximize effective investments in increasing PA and decreasing sedentary time among children and young people in Chile.

\section{Acknowledgments}

We thank the collaboration of Matias Portela (Ministry of Health, MINSAL), Gilda San Martin (Ministry of Sports), Andrea Vio Toro (Junta Nacional Escolar y Becas, JUNAEB) and Patricio Roman (Ministry of Health, MINSAL). This work was supported by CONICYT FONDECYT 201611160720 and Universidad de La Frontera DFP18-0022.

\section{References}

1. Aguilar-Farias N,Cortinez-O'Ryan A, Sadarangani KP, et al. Results from Chile's 2016 report card on physical activity for children and youth. J Phys Act Health. 2016;13(11 suppl 2):S117-S123.

2. Ministerio de Desarrollo Social de Chile. Encuesta de Actividades de Niños, Niñas y Adolescentes 2012 (EANNA 2012). 2013.

3. Aguilar-Farias N, Martino-Fuentealba P, Carcamo-Oyarzun J, et al. A regional vision of physical activity, sedentary behaviour and physical education in adolescents from Latin America and the Caribbean: results from 26 countries. Int J Epidemiol. 2018;47(3):976-986.

4. Organisation for Economic Co-operation and Development. PISA 2015 Results (Volume III): Students' Well-Being. 2017.

5. Junta Nacional de Auxilio Escolar y Becas (JUNAEB). Encuesta de Vulnerabilidad 2017 (EV 2017). 2018.

6. Ministerio de Salud de Chile. Encuesta Nacional de Calidad de Vida 2015-2016 (ENCAVI). 2017.

7. Ministerio de Vivienda y Urbanismo. Encuesta de Percepción de Calidad de Vida Urbana (EPCVU 2015). 2016.

8. Garcia-Hermoso A, Saavedra JM, Olloquequi J, Ramirez-Velez R. Associations between the duration of active commuting to school and academic achievement in rural Chilean adolescents. Environ Health Prev Med. 2017;22(1):31.

9. Rodriguez-Rodriguez F, Cristi-Montero C, Celis-Morales C, Escobar-Gomez D, Chillon P. Impact of distance on mode of active commuting in chilean children and adolescents. Int $J$ Environ Res Public Health. 2017;14(11):pii:E1334.

10. Barja Yanez S, Arnaiz Gomez P, Villarroel Del Pino L, et al. [Dyslipidemias in school-age chilean children: prevalence and associated factors]. Nutr Hosp. 2015;31(5):2079-2087.

11. Garcia-Hermoso A, Marina R. Relationship of weight status, physical activity and screen time with academic achievement in adolescents. Obes Res Clin Pract. 2017;11(1):44-50.

12. Agencia de Calidad de la Educación. Estudio Nacional de Educación Física 2015 (ENEF). 2016.

13. Ministerio de Salud de Chile. Encuesta Nacional de Salud (ENS) 2016-2017. 2018.

14. Olivares PR, Cossio-Bolaños MA, Gomez-Campos R, AlmonacidFierro A, Garcia-Rubio J. Influence of parents and physical education teachers in adolescent physical activity. Int J Clin Health Psychol. 2015;15(2):113-120.

15. Ministerio del Deporte GdC. Politica Nacional de Actividad Física y Deporte 2016-2025. 2016. 